Karstenia 42: 27-28, 2002

\title{
Caloscyphaceae, a new family of the Pezizales
}

\author{
HARRI HARMAJA
}

\begin{abstract}
HARMAJA, H. 2002: Caloscyphaceae, a new family of the Pezizales. - Karstenia 42: 27-28. Helsinki. ISSN 0453-3402.

The new family Caloscyphaceae Harmaja is described for Caloscypha Boud. (Ascomycetes, Pezizales). The genus is monotypic, only comprising C. fulgens (Pers. : Fr.) Boud. Characters believed to be diagnostic of the new family are treated, some of them being cited from the literature, others having been studied personally.
\end{abstract}

Key words: ascospore wall, Cáloscypha, carotenoids, chemotaxonomy, Geniculodendron pyriforme, phylogeny, seed parasite

Harri Harmaja, Botanical Museum, Finnish Museum of Natural History, P.O. Box 47, FIN-00014 University of Helsinki, Finland www.helsinki.fi/people/harri.harmaja/

The genus Caloscypha Boud., with its only species $C$. fulgens (Pers. : Fr.) Boud., has usually been included in the family Pyronemataceae (Pezizales). However, since a rather long time the genus been considered taxonomically isolated without having close relatives (see e.g. Korf 1972). This status was strengthened as the spores of $C$. fulgens were reported to belong to an infrequent kind as to their wall structure (Harmaja 1974). As I also observed that the ascus wall is often somewhat thickened upwards (up to 3.0 $\mathrm{mm}$ in Melzer's reagent; unpublished until now), I even prepared a manuscript in the 1970's to describe a new family for Caloscypha. After those times, two additional special characteristics of Caloscypha have been detected: ( $i$ ) the nutrition mode: Geniculodendron pyriforme G. A. Salt, pathogenic to the seeds of Abies, Picea and Pinus, was found to be the anamorph of $C$. fulgens (see e.g. Sutherland 1979), (ii) according to Landvik et al. (1997) the genus unexpectedly is phylogenetically distinct from the other cupulate, carotenoid-containing taxa with uninucleate spores: of the three main lineages of the Pezizales the genus clusters with one that comprises the families Helvellaceae, Morchellaceae and Tuberaceae (and obviously also Discinaceae and Rhizinaceae; see O'Donnell \& al. 1997). In these families, the apothecia are non-bright in colour, de- void of carotenoid pigments, and the spores are multinucleate. The genus clearly deserves a family of its own.

Below, the new family Caloscyphaceae is described. The characters that appear to be diagnostic at the family level are given in the English description; these are partly a matter of personal judgement. Detailed features of the genus Caloscypha and its only species have been described e.g. by Eckblad (1968); see also Harmaja (1974) for some spore characters.

\section{Caloscyphaceae Harmaja, familia nova}

Familia ordinis Pezizales inter Ascomycetes. Mycelium in seminibus coniferarum parasiticum. Apothecia vernalia, cupulata, hymenio luteo. Asci inamyloidei. Paraphyses saepe apice attenuati, pigmenta carotenoidea continentes. Sporae hyalinae, uninucleatae, laeves, sine tunica secundaria cyanophiloidea, intus eguttulatae. Excipulum e textura intricata. - Typus: Caloscypha Boud.

Family of Ascomycetes: Pezizales. Apothecia cupulate, hymenium deep yellow. Ascus wall inamyloid. A proportion of the paraphyses taper apically. Carotenoid pigments present within the paraphysis cells (Arpin 1968). Ascospores hyaline, uninucleate (Berthet 1964), smooth, without 
a cyanophilic secondary wall at any stage of their development (Harmaja 1974), without oil drops. Excipulum essentially of textura intricata. Mycelium pathogenic to conifer seeds. Apothecia occur in spring on forest ground. Phylogenetic analysis suggests an affinity to the families Helvellaceae, Morchellaceae and Tuberaceae (Landvik \& al. 1997).

\section{References}

Arpin, N. 1968: Les caroténoides des Discomycètes: essai chimiotaxinomique. - Université de Lyon, Villeurbanne. 170 pp.; reissued 1969: Bull. Mens. Soc. Linn. Lyon 38 (suppl.): 1-169.

Berthet, P. 1964: Essai biotaxinomique sur les Discomycètes. - Joanny Lorge, Lyon. $157 \mathrm{pp}$.
Eckblad, F.-E. 1968: The genera of the operculate Discomycetes. A re-evaluation of their taxonomy, phylogeny and nomenclature. - Nytt Mag. Bot. 15: 1191.

Harmaja, H. 1974: Observations on the presence of a cyanophilic perispore in the spores of the Pezizales. Karstenia 14: 123-125.

Korf, R.P. 1972: Synoptic key to the genera of the Pezizales. - Mycologia 64: 937-994.

Landvik, S., Egger, K.N. \& Schumacher, T. 1997: Towards a subordinal classification of the Pezizales (Ascomycota). - Nordic J. Bot. 17: 403-418.

O'Donnell, K., Cigelnik, E., Weber, N. S. \& Trappe, J. M. 1997: Phylogenetic relationships among ascomycetous truffles and the true and false morels inferred from $18 \mathrm{~S}$ and $28 \mathrm{~S}$ ribosomal DNA sequence analysis. - Mycologia 89: 48-65.

Sutherland, J.R. 1979: The pathogenic fungus Caloscypha fulgens in stored conifer seeds in British Columbia and relation of its incidence to ground and squirrel-cache collected cones. - Canad. J. Forest Res. 9: 129-132. 